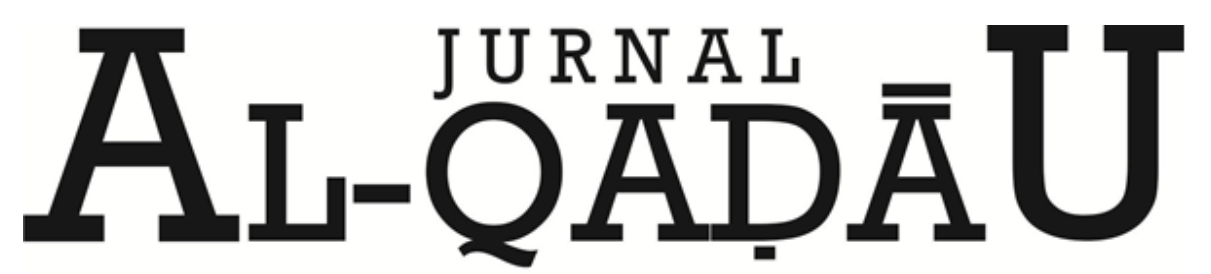

PERADILAN dan HUKUM KELUARGA ISLAM

\title{
Implementasi Dispensasi Nikah dalam Tinjauan Undang-Undang Nomor 23 Tahun 2002 Tentang Perlindungan Anak di Pengadilan Agama Takalar
}

Implementation of Marriage Dispensation in Review of Regulation Number 23 Year 2002 Concerning Child Protection at Religious Court of Takalar.

Jasmianti Kartini Haris

Universitas Muslim Indonesia

Email: Jasmiantiharis@gmail.com

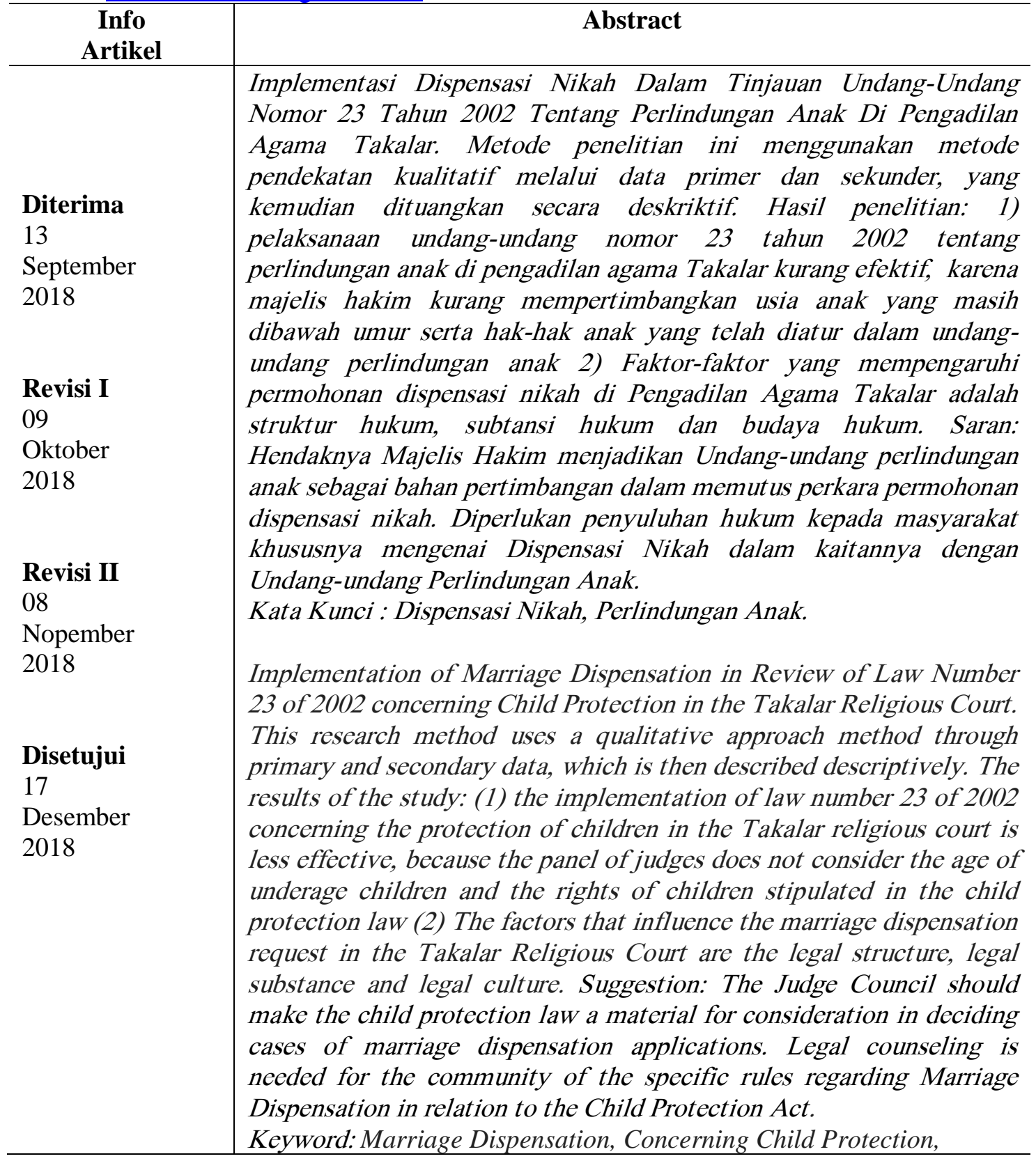




\section{A. PENDAHULUAN}

Negara dan pemerintah membuat batasan minimal umur untuk seseorang dapat melakukan perkawinan, karena mempunyai kepentingan sekaligus kewajiban untuk mengawal dan mengarahkan perkawinan sebagai institusi sosial yang melindungi sekaligus mengangkat harkat dan martabat perempuan (Yusuf Hanafi. 2011:10).

Perkawinan mempunyai arti penting dalam kehidupan manusia dimana perkawinan menimbulkan akibat-akibat hukum, bukan hanya kepada suami/isteri yang bersangkutan, melainkan juga kepada anak-anak dan/atau keturunannya, orangtua, keluarga, dan masyarakat pada umumnya. Perkawinan merupakan suatu lembaga suci yang bertujuan untuk membentuk keluarga yang bahagia dan kekal, sesuai dengan Undang-Undang Perkawinan Dalam pasal 1 ayat (1) UU No.7 Tahun 1974 tentang perkawinan, menyatakan;

Bahwa perkawinan ialah ikatan lahir batin antara seorang pria dengan seorang wanita sebagai suami isteri dengan tujuan membentuk keluarga (rumahtangga) yang bahagia dan kekal berdasarkan Ketuhanan Yang Maha Esa.

Untuk mewujudkan perkawinan yang ideal sesuai al-Qur'an dan undangundang bukanlah perkara mudah, tapi tidak berarti hal itu sulit untuk diwujudkan. Perkawinan tidak boleh sekadar sebuah tradisi formalitas yang berkaitan dengan halhal yang bersifat administrative, ia tidak boleh mengalami kehilangan makna, sehingga pada akhirnya perkawinan hanya menjadi wahana yang terdistorsi oleh kesadaran manusia yang lemah (Andi Syamsu Alam, 2005:29).

Di Indonesia untuk memberikan perlindungan serta menjaga agar pernikahan berjalan dengan baik, sehat dan terjaga kelanggengannya, maka dalam Undangundang Nomor 1 Tahun 1974 tentang perkawinan diberikan batasan umur seseorang dapat melaksanakan pernikahan,agar terwujud sebuah pernikahan yang ideal dengan umur yang matang. Batasan umur yang ditetapkan adalah 19 Tahun bagi laki-laki dan 16 Tahun bagi perempuan,(pasal 7 ayat 1 UU Nomor 1 Tahun 1974). Dalam pasal ini terkandung beberapa prinsip untuk menjamin cita-cita luhur perkawinan,yaitu asas sukarela,partisipasi keluarga dan kedewasaan calon mempelai yaitu kedewasaan fisik dan mental kedua calon mempelai (Mufidah.2010:63).

Kematangan fisik dan mental kedua calon mempelai yang merupakan hal yang urgen karena dalam perkawinan kedewasaan dan rasa tanggung jawab yang besar sangat diperlukan dalam membentuk keluarga. Kedewasaan ini diaplikasikan dengan pola relasi yang sejajar dan menganggap pasangan sebagai mitra/partner,sehingga komunikasi dalam rumah tangga tersebut berjalan sesuai harapan. Prinsip kematangan calon mempelai juga dimaksudkan bahwa calon suami isteri harus telah matang jasmani dan rohani untuk melangsungkan perkawinan,agar dapat memenuhi tujuan luhur perkawinan. Pernikahan merupakan penyatuan antara dua karakter dan latar belakang yang berbeda, dan tidak menutup kemungkinan adanya perbedaan dari segi usia karena telah dianggap dewasa, pada umumnya dewasa yang dimaksudkan ialah telah cakap untuk melakukan segala perbuatan hukum. Kecakapan seseorang dalam melakukan perbuatan hukum memerlukan kedewasaan, dan kedewasaan dipengaruhi oleh umur. Berikut konsep yang dipakai dalam KUH Perdata tentang ukuran kedewasaan seseorang, yang dinyatakan dalam ketentuan Pasal 330 KUH Perdata, orang dewasa adalah mereka-mereka yang; 
a. telah mencapai umur 21 tahun atau lebih;

b. mereka yang telah menikah, sekalipun belum berusia 21 tahun (J. Satrio, 1951:63)

Dalam Undang-Undang No. 39 Tahun 1999 Tentang Hak Asasi Manusia memiliki pengertian tentang kedewasaan. Seseorang telah dianggap dewasa apabila telah berusia 18 (delapan belas) tahun dan belum menikah. Disamping itu Undang-Undang No. 23 Tahun 2006 Tentang Administrasi Kependudukan mengatur setiap penduduk warga negara Indonesia yang telah berumur 17 (tujuh belas) tahun wajib memiliki KTP (Kartu Tanda Penduduk), meskipun tidak tertulis secara jelas kata dewasa akan tetapi masyarakat mengganggap usia 17 (tujuh belas) tahun dapat dikatakan telah dewasa, hal ini merujuk pada Undang-Undag Pemilu yang memberikan hak suara kepada warga Negara yang telah mencapai usia 17 (tujuh belas) tahun.

Sedangkan dalam hukum Islam usia yang dipautkan dalam perkawinan, dipersyaratkan yang telah mencapai baligh. Sehingga secara tegas harus memenuhi ketentuan hukum Islam yang sesuai dengan ketentuan pasal 2 ayat (1) tahun 1974 tentang Perkawinan. Dalam KHI Pasal 15 secara tegas telah menyebutkan bahwa batas umur minimal calon mempelai yang akan menikah adalah 16 tahun bagi perempuan dan 19 tahun bagi laki-laki.

Keluarga bahagia dan sejahtera perlu dipersiapkan dalam perkawinan yang matang antara lain persiapan fisik. Dengan bekal kesehatan,kedewasaan,serta kemampuan membiayai hidup rumah tangga,berarti calon suami isteri yang akan memasuki kehidupan rumah tangga telah menyiapkan modal dasar bagi usaha membina dan mengembankan kehidupan rumah tangga. Tanpa persiapan fisik seperti itu,kehidupan dan kelapangan rumah tangga akan menjadi rawan,akhirnya mengakibatkan kegagalan. Oleh karena itu,harus dicegah adanya perkawinan dibawah umur.

Meskipun dalam Undang-undang telah menetapkan batasan usia perkawinan sedemikian rupa, namun tidak menutup kemungkinan seseorang menikah dibawah umur tersebut. Seseoang yang belum mencapai umur yang ditetapkan tetap dapat melakukan perkawinan dengan syarat mendapatkan izin dari walinya dan dari pengadilan agama. Di pengadilan agama permohonan izin menikah disebut dengan permohonan dispensasi nikah.

Dispensasi nikah secara absolute memang menjadi kompetensi Pengadilan Agama berdasarkan ketentuan Pasal 7 ayat (2) jis Pasal 63 UU No. 1 Tahun 1974, Pasal 49 huruf (a) UU Nomor 7 Tahun 1989 yang telah diubah dengan UU Nomor 3 Tahun 2006 dan perubahan kedua dengan UU Nomor 50 Tahun 2009. Ihwal mengapa seseorang memerlukan lembaga hukum ini sebenarnya hanya persoalan umur. Dalam hal ini, ketika seseorang belum mencapai batas minimal usia yang diizinkan oleh Undang-undang untuk melaksanakan perkawinan, yaitu 19 tahun bagi calon mempelai pria dan 16 tahun bagi calon mempelai wanita. Dengan kata lain, apabila seseorang ingin melangsungkan perkawinan sementara usianya belum mencapai batas usia minimal tersebut, maka dia harus mengajukan dispensasi nikah ke Pengadilan Agama. 
Dilihat dari berbagai peraturan perundangan ternyata memberikan batasan umur yang berbeda tentang siapa yang disebut dengan anak. Berikut beberapa batasan umur seseorang disebut sebagai anak, antara lain:

1. KUHPerdata Tahun 1847 Pasal 330 ayat (1) menyatakan:

"Seorang belum dapat dikatakan dewasa jika orang tersebut umurnya belum genap 21 Tahun, kecuali seseorang tersebut telah menikah sebelum umur 21 Tahun"

2. KUHP Pasal 45 menyatakan anak yang belum dewasa apabila seeorang tersebut belum berumur 16 Tahun.

3. Undang-undang Nomor 4 Tahun 1979 Tentang Kesejahteraan Anak Pasal 1 ayat 2 menyatakan:

"Anak adalah seseorang yang belum mencapai umur 21 Tahun dan belum pernah menikah"

4. Konvensi Hak-hak anak yang dikeluarkan pada Tahun 1989 menyatakan Anak adalah setiap manusia yang berusia dibawah 18 Tahun kecuali berdasarkan yang berlaku bagi anak tersebut ditentukan bahwa usia dewasa dicapai lebih awal.

5. Undang-undang Nomor 3 Tahun 1997 Tentang Pengadilan Anak Pasal 1 ayat 1 yang berisi:

"Anak adalah orang yang dalam perkara Anak nakal telah mencapai umur 8 Tahun dan belum pernah menikah".

6. Undang-undang Nomor 25 Tahun 1997 tentang ketenagakerjaan pasal 1 ayat 20 menyatakan bahwa Anak adalah orang laki-laki atau wanita yang berumur kurang dari 15 Tahun.

7. Undang-undang Nomor 39 Tahun 1999 tentang HAM pasal 1 ayat 5 menyatakan bahwa Anak adalah setiap manusia yang berusia dibawah 18 Tahun dan belum menikah, termasuk anak yang masih dalam kandungan apabila hal tersebut adalah demi kepentingannya.

8. Undang-undang RI Nomor 23 Tahun 2002 tentang Perlindungan Anak Pasal 1 ayat 1 menyatakan bahwa Anak adalah seseorang yang belum berusia 18 Tahun, termasuk anak yang masih dalam kandungan.

9. Undang-undang RI Nomor 21 Tahun 2007 tentang Pemberantasan Tindak Pidana Perdagangan Orang Pasal 1 ayat 5 menyatakan bahwa Anak adalah seseorang yang belum berusia 18 Tahun, termasuk anak yang masih dalam kandungan.

10. Undang-undang Nomor 44 Tahun 2008 tentang Pornografi pasal 1 ayat 4 yang disebut anak adalah seseorang yang belum berusia 18 Tahun.

Orang tua memegang peranan yang cukup penting terhadap terwujudnya perlindungan anak dan kesejahteraan anak. Meskipun Undang-undang perkawinan telah mengatur batasan usia minimal perkawinan bagi laki-laki berumur minimal 19 Tahun dan 16 tahun bagi perempuan,orang tua tidak boleh serta merta mengizinkan atau merestui perkawinan tersebut. Orang tua harus mampu berfikir jernih dan bijaksana dalam mengambil keputusan terkait perkawinan bagi anak mereka. Kewajiban orang tua ini sesuai dengan ketentuan pasal 26 ayat (1) huruf (c ) Undang-undang Nomor 23 Tahun 2002 tentang perlindungan anak. 
Apabila melihat ketentuan pasal 26 ayat 1 huruf c Undang-undang Nomor 23 Tahun 2002 tentang Perlindungan Anak dengan tegas melarang terjadinya pernikahan anak dibawah umur yang belum berusia 18 Tahun, begitu juga batasan usia menikah dalam pasal 7 ayat 1 UU Nomor 1 Tahun 1974 tentang Perkawinan. Namun pada saat yang sama pasal 7 ayat 2 UU Nomor 1 Tahun 1974 didalamnya juga diperbolehkan seseorang untuk mengajukan permohonan dispnsasi nikah. Sepintas ada kontradiksi antara UU Perlindungan Anak dengan UU Perkawinan perihal Perkawinan anak dibawah umur.

Namun, jika melihat pada portal resmi Pengadilan Agama Takalar di awal tahun 2018 dengan jenjang waktu bulan Januari-Maret, telah ada beberapa permohonan yang mengajukan dispensasi nikah, dan penuli melihat dari tiga tahun terakhir 2015-2017, terdapat 977 perkara yang telah diputus dan berkekuatan hukum tetap 30 diantaranya adalah perkara dispensasi nikah, apabila terjadi peningkatan tiap tahunnya,bagaimanakah pertimbangan hakim dalam memberikan penetapannya di Pengadilan Agama Kelas II Takalar, dengan mensinkronkan kondisi hari ini dan kontrasnya permohonan hak tentang tujuan hidup dan bedanya pandangan usia dewasa. Pengadilan Agama juga berwenang membuat penetapan asal usul seorang anak dan penetapan pengangkatan anak, adopsi berdasarkan hukum Islam, gugatan/permohonan pengakuan anak, gugatan nafkah anak, isbat nikah dalam rangka untuk mengurus akta kelahiran anak,dll. Itu diantara kewenangan Pengadilan Agama yang ada keterkaitannya dengan Undang-undang Perlindungan Anak.

Di era modern seperti saat ini, dengan kondisi negara yang semakin berkembang, dengan berbagai kesibukan pekerjaan dan aktifitas lainnya tak jua menyurutkan hasrat bagi seseorang untuk membina rumah tangga. Pernikahan tetap menjadi kebutuhan bagi seseorang yang berstatus masih sendiri, mengingat hal ini juga merupakan anjuran agama, yang bahkan amalannya disandingkan dengan seperdua dari agama Islam. Terlepas dari konsep umum yang melekat, jika ditelisik dan diperhatikan kembali, ternyata tidak sedikit pasangan yang melakukan pernikahan dibawah umur sesuai undang-undang yang berlaku. Dalam sebuah wawancara lepas (pra penelitian) oleh peneliti dengan seorang hakim di salah satu Pengadilan Agama, mengatakan, bahwa dispensasi nikah mulai menjadi perhatian serius dan hampir disetiap tahun - beberapa waktu setelah bulan ramadhan, permohonan dispensasi nikah tak sepi dari pendaftaran perkara. Sebagaimana menurut Andi Syamsu Alam (2005:69), jangan sampai dispensasi yang berkaitan dengan ketentuan Pasal 7 ayat (2) terkesan "menggampangkan" proses perkawinan tanpa mempertimbangkan keharmonisan hidup keluarga kelak di masa-masa yang akan datang. Jika orientasinya hanya dalam konteks pemenuhan nafkah batin (salah satunya: hubungan seks), maka makna perkawinan menjadi hilang dan tidak sejalan dengan indikasi hukum perkawinan Islam, ataukah ada alasan lain penyebab permohonan dispensasi nikah tersebut dan dapat diminimalisir.

Pada Pasal 26 ayat 1 huruf c Undang-undang Nomor 23 Tahun 2002 tentang Perlindungan Anak dengan pasal 7 ayat 1 UU Nomor 1 Tahun 1974 tentang Perkawinan adalah kehendak dari undang-undang itu sendiri, meskipun terdapat pengecualian pada pasal 7 ayat 2 UU Nomor 1 tahun 1974. Namun pada kenyataannya masih banyak permohonan dispensasi nikah yang dikabulkan tanpa 
menjadikan undang-undang perlindungan anak sebagai bahan pertimbangan yang seakan-akan pengadilan agama hanya sebatas membuka pintu izin dispensasi nikah.

Berdasarkan latar belakang tersebut maka dari itu peneliti tertarik untuk mengkaji lebih lanjut mengenai implementasi dispensasi nikah dalam tinjauan uu no. 23 tahun 2002 tentang perlindungan anak di pengadilan agama takalar.

\section{B. METODOLOGI PENELITIAN}

Pendekatan penelitian yang digunakan dalam penelitian ini adalah pendekatan kualitatif. Penelitian kualitatif adalah penelitian tentang riset yang bersifat deskriptif dan cenderung menggunakan analisis. Proses dan makna (perspektif subjek) lebih ditonjolkan dalam penelitian kualitatif, landasan teori dimanfaatkan sebagai pemandu agar fokus penelitian sesuai dengan fakta di lapangan. Selain itu landasan teori juga bermanfaat untuk memberikan gambaran umum tentang latar penelitian dan sebagai bahan pembahasan hasil penelitian, dan dalam penelitian kualitatif peneliti bertolak dari data, memanfaatkan teori yang ada sebagai bahan penjelas.

Tipe penelitian yang digunakan adalah penelitian hukum normatif empiris. Penelitian hukum normatif empiris adalah merupakan penggabungan antara pendekatan hukum normatif dengan adanya penambahan berbagai unsur empiris. Penelitian hukum normatif empiris adalah mengenai implementasi ketentuan hukum normatif (undang-undang) dalam aksinya pada setiap peristiwa hukum tertentu yang terjadi dalam suatu masyarakat. Penelitian hukum normatif empiris ini digunakan untuk mengkaji aturan-aturan yang berkaitan dengan Implementasi Dispensasi Nikah Dalam Tinjauan UU No. 23 Tentang Perlindungan Anak di Pengadilan Agama Takalar.

\section{TINJAUAN TEORETIS Pengertian Dispensasi Nikah}

Zainal Bahry (1996:55) dispensasi adalah kelonggaran, pengecualian, memberikan keringanan, memberikan kelonggaran dalam hal khusus dari ketentuan undang-undang. Roihan A. Rasyid (1988 : 32) berpendapat bahwa dispensasi kawin adalah dispensasi yang diberikan Pengadilan Agama kepada calon mempelai yang belum mencapai 19 (sembilan belas) tahun dan wanita belum mencapai 16 (enam belas) tahun. Dispensasi kawin diajukan oleh para pihak Pengadilan Agama yang ditunjuk oleh orang tau masing-masing.Pengajuan perkara permohonan diajukan dalam bentuk permohonan (voluntair) bukan gugatan, dan jika calon suami istri beragama non Islam maka pengajuan permohonannya ke Pengadilan Negeri.

\section{Syarat-syarat Dispensasi Nikah}

Dispensasi nikah diperlukan bagi calon pengantin pria yang belum berumur 19 (sembilan belas) tahun dan calon pengantin wanita belum berumur 16 (enam belas) tahun. Sebagaimana ditentukan dalam Undang-undang No 1 Tahun 1974 bahwa Perkawinan hanya diizinkan jika pihak pria mencapai umur 19 tahun dan pihak wanita sudah mencapai umur 16 (enam belas) tahun Undang-undang No.1 Tahun 1974 pasal 7 ayat 1. Dalam hal penyimpangan terhadap ayat (1) pasal ini dapat meminta dispensasi kepada pengadilan atau pejabat lain, yang ditunjuk oleh kedua orang tua pihak pria maupun pihak wanita Undang-undang No.1 Tahun 1974 pasal 7 ayat 2 . 
Selanjutnya dalam pelaksanaan teknis ketentuan Undang-undang itu, dalam Permeneg No.3 tahun 1975 ditentukan: dispensasi Pengadilan Agama, adalah penetapan yang berupa dispensasi untuk calon suami yang belum mencapai umur 19 (sembilan belas) tahun dan atau calon istri yang belum mencapai umur 16 (enam belas) tahun yanag dikeluarkan oleh Pengadilan Agama. Permeneg No.3 Tahun 1975 pasal 1 ayat 2 sub g, Apabila seorang calon suami belum mencapai umur 19 (sembilan belas) tahun dan calon istri belum mencapai umur 16 (enam belas) tahun hendak melangsungkan pernikahan harus harus mendapat dispensasi dari Pengadilan Agama permeneg No.3 tahun1975 pasal 13 ayat 1.

Permohonan dispensasi nikah bagi mereka tersebut pada ayat (1) pasal ini, diajukan oleh orang tua pria mupun wanita kepada pengadilan agama yang mewilayahi tempat tinggalnya; (permeneg No.Tahun 1975 pasal 13 ayat 2.)

Pengadilan Agama setelah memeriksa dalam persidangan, dan berkeyakinan, bahwa terdapat hal-hal yang memungkinkan untuk memberikan dispensasi tersebut, maka Pengadilan Agama memberikan dispensasi nikah dengan suatu penetapan; (permeneg No.Tahun 1975 pasal 13 ayat 3). Dalam hal permohonan dispensasi perkawinan ini harus dari orang tua atau wali calon pengantin, jadi bukan calon pengantin itu seperti pada permohonan izin kawin bagi yang belum berumur.

Mekanisme pengajuan perkara dispensasi nikah sama dengan mekanisme pengajuan perkara gugatan. Adapun mekanisme pengajuan dispensasi nikah, yaitu:

1. Sebelum pemohon mengajukan permohonannya, pemohon ke prameja terlebih dahulu untuk memperoleh penjelasan tentang bagaimana cara berperkara, cara membuat surat permohonan, dan di prameja pemohon dapat minta tolong untuk dibuatkan surat permohonan.

2. Surat permohonan yang telah dibuat dan ditandatangani diajukan pada sub kepaniteraan permohonan, pemohon menghadap pada meja pertama yang akan menaksir besarnya panjar biaya perkara dan menuliskanya pada surat kuasa untuk membayar (SKUM). Besarnya panjar biaya perkara diperkirakan harus telah mencukupi untuk menyelesaikan perkara tersebut yang berdasarkan pasal $193 \mathrm{R} . \mathrm{Bg}$ atau pasal 182 ayat (1) HIR atau pasal 90 ayat (1) UUPA.

3. Pemohon kemudian menghadap kepada kasir dengan menyerahkan surat permohonan dan SKUM. Kasir kemudian menerima uang tersebut dan mencatat dalam jurnal biaya perkara, menandatangani dan memberi nomor perkara serta tanda lunas pada SKUM, dan mengembalikan surat permohonan dan SKUM kepada Pemohon.

4. Pemohon kemudian menghadap pada Meja II dengan menyerahkan surat permohonan dan SKUM yang telah dibayar.

Proses penyelesaian perkara permohonan dispensasi kawin di Pengadilan Agama, ketua majelis hakim setelah menerima berkas perkara, bersama-sama hakim anggotanya mempelajari berkas perkara. Kemudian menetapkan hari dan tanggal serta jam kapan perkara itu disidangkan serta memerintahkan agar para pihak dipanggil untuk datang menghadap pada hari, tanggal, dan jam yang telah ditentukan. Kepada para pihak diberitahukan pula bahwa mereka dapat mempersiapkan bukti-bukti yang diajukan dalam persidangan. 
Namun, biasanya bukti-bukti sudah dititipkan kepada panitera sebelum persidangan.Setelah persidangan dibuka dan dinyatakan terbuka untuk umum oleh ketua majelis, maka para pihak berperkara dipanggil ke ruang persidangan. Kemudian ketua majelis berusaha menasehati pemohon, anak pemohon dan calon anak pemohon dengan memberikan penjelasan tentang sebab akibatnya apabila pernikahan dilakukan belum cukup umur dan kemudian ketua majelis membacakan surat permohonan pemohon yang telah didaftarkan di kepaniteraan pengadilan agama. Selanjutnya ketua majelis memulai pemeriksaan dengan pertanyaanpertanyaan yang diajukan kepada pemohon, anak pemohon dan calon anak pemohon secara bergantian. Kemudian ketua majelis melanjutkan pemeriksaan bukti surat, dan pemohon menyerahkan bukti surat.

Undang-undang No.1 Tahun 1974 dan Peraturan Pemerintah No. 9 Tahun 1975 mengatur secara jelas apa saja yang dapat dijadikan sebagai alasan agar diberikannya dispensasi kawin. Oleh karena itu, tiap-tiap keadaan dalam setiap perkara permohonan dispensasi nikah akan dipertimbangkan oleh majelis hakim dalam pemerikasaan di persidangan. Apabila Pengadilan terpaksa menolak permohonan tersebut berarti dispensasi usia kawin tidak dapat diberikan. Akibatnya perkawinan tidak dapat dilaksanakan karena kurangnya persyaratan.Hal-hal yang menentukan dispensasi nikah dapat diberikan atau tidak, bukan hanya berdasarkan atas dasar-dasar yuridis namun juga berdasarkan pertimbangan atau alasan-alasan penting lainnya, seperti misalnya keyakinan hakim.

\section{Perkawinan}

Asmin dalam bukunya yang dikutip dari (Prof. Mr. Subekti,1986:16) Mengatakan bahwa perkawinan ialah pertalian yang sah antara seorang lelaki dan seorang perempuan untuk waktu yang lama. Pengertian pertalian yang sah adalah hubungan antara dua orang yang berbeda jenis yang telah memenuhi ketentuanketentuan yang berlaku, dan sebaliknya hubungan diantara mereka itu tanpa menyalahi hukum yang dijunjung tinggi.

Dalam Kompilasi Hukum Islam (KHI) Bab II Pasal 2 :

Perkawinan menurut hukum Islam adalah pernikahan yaitu akad yang sangat kuat atau mitsaqan ghalidzan untuk mentaati perintah Allah dan melaksanakannya merupakan ibadah.

Menurut Abdu al-Rahmān al-Jaziiri (dalam Nur Taufik Sanusi, 2010:5) kata kawin atau nikah dapat didekati dari tiga aspek pengertian (makna), yakni makna lughawi (etimologis), makna Ushuuli (Syar'i) dan makna Fiqh (hukum). Perkawinan disebut dengan al-Ziwaaj, yang secara lughawi (etimologis) berasal dari kata al-Zawj atau al-Zijah, diambil dari kata zaaja-yajuu-zawjan,yang secara harfiah berarti: menghasut, menaburkan benih, perselisihan, mengadu domba, akan tetapi al-zawaj yang dimaksud dalam hal ini ialah al-zawaaj yang diambil dari kata zawwajayuzawwiju-tazwiijan, dari bentuk timbangan fa'ala-yufa'ilu-taf'ilan, yang berarti mengawinkan,mencampuri,menemani,mempergauli, menyertai dan memperistri. Adapun pernikahan,berasal dari kata nakahaa, yankihuu, nikaahan yang berarti alwath'u (berjalan di atas, melalui, memijak menginjak, memasuki, menaiki, menggauli, bersetubuh dan bersenggama), al-Dатmu (mengumpulkan, memegang, menggenggam, menyatukan, menggabungkan, menyandarkan, merangkul, memeluk 
dan menjumlahkan) al-Jam'u (mengumpulkan, menghimpun, menyatukan, menggabungkan, menjumlahkan dan menyusun).

Menurut Al-Kahlan (dalam Kadar M. Yusuf, 2013:190) di dalam surah anNisaa'(4) terdapat kata inkihuu dalam ayat ini merupakan fi'il amar jamak dari kata inkih. Kata dasarnya dalah nakaha.Secara etimologi kata ini berarti wathak atau jima' (mempergauli istri).Sebagian ahli bahasa menyebutkan pula bahwa makna dasarnya ialah 'aqad. Kedua makna ini dapat dipakai dalam bahasa arab. Nikah dalam arti jima' seperti yang tergambar dalam sabdah Rasulullah "Lakukanlah segala sesuatu, kecuali jima' (nikah)”. HR. Muslim.

Kata nikah dalam ayat ini berarti 'aqad, yaitu suatu ijab dan Kabul dilakukan oleh wali seorang wanita dan calon suami, dimana aqad itu membolehkan laki-laki mencampuri wanita yang dikabulnya dalam 'aqad tersebut;

Selanjutnya, Ibnu Manzhur, Jamaluddin (dalam kadar m. Yusuf, 2013:191) Kata al-'adl. Secara bahasa kata ini dimaknai dengan al-istiqaamah (konsisten).Secara syar'i, kata 'adalah diartikan kepada "menjauhkan diri dari segala sesuatu yang dilarang agama.Pengertian 'adil yang dipakai ini merupakan lawan dari fasik, seperti istilah 'adil yang dipakai dalam kajian hadis dan hukum Islam. Disamping itu, kata 'al-adl dalam ayat ini dapat dimaknai pula dengan "kemampuan dalam jiwa seseorang menghalangi dirinya untuk berbuat perbuatan yang dilarang." Kata ' $a l$-adl ini dapat dimaknai dengan pengertian 'al-adl yang terakhir, yaitu seorang suami harus berbuat adil terhadap istrinya.

Kemudian kata shaduqat merupakan jamak dari shadaqah, yang berarti suatu pemberian. Ia juga disebut dengan mahar atau maskawin karena masakawin itu adalah harta yang diberikan kepada istri sebagai tanda atau syarat terjadinya ikatan perkawinan antara seorang lelaki dan wanita.

Perkawinan merupakan momentum yang sangat penting bagi perjalanan hidup manusia. Disamping membawa kedua mempelai kealam lain yang berbeda, perkawinan juga secara otomatis akan mengubah status keduanya, setelah perkawinan kedua belah pihak akan menerima beban yang berat dan tanggung jawab masing-masing. Tanggung jawab dan beban itu, bukanlah sesuatu yang mudah dilaksanakan sehingga mereka harus sanggup dan memikul melaksanakan, (Amir Nuruddin dan Azhari Akmal, 2004:39)

Secara umum, perkawinan adalah sebuah perilaku turun temurun dari umat manusia sebagai sebuah sarana yang dipandang baik dan benar untuk melanjutkan proses regenerasi dan kesinambungan hidup dan kehidupan umat manusia itu snediri. Perkawinan merupakan ikatan yang sangat suci dan kokoh antara sepasang anak manusia yang diharapkan akan mampu menjalin sebuah ikatan lahir-batin antara suami istri sebagai modal untuk menciptakan rumah tangga yang sakinah mawaddah wa rahmah, yaitu keluarga bahagia yang diridhai Allah swt. seperti yang tertuang dalam KHI Bab II Pasal 3:

Perkawinan bertujuan untuk mewujudkan kehidupan rumah tangga yang sakinah, waddah wa rahmah.

Nurcholish Majid (dalam Andi Syamsu Alam 2005:25), juga secara tegas menerangkan bahwa:

Perkawinan yang baik adalah sebuah ikatan seumur hidup, yang disahkan oleh Tuhan.Perkawinan memerlukan banyak daripada sekadar "peduli", 
"pemenuhan diri" dan "komitmen". Perkawinan memerlukan adanya kesadaran tentang kehadiran Tuhan dalam hidup manusia, kehadiran Sang Maha Pencipta yang akan membimbing kita ke jalan yang lurus ke jalan yang sejati dan abadi. Perkawinan menuntut masing-masing kita jujur pada diri sendiri, kepada jodoh kita masing-masing, dan kepada Tuhan.

Dalam hal ini tujuan perkawinan menurut hukum Islam terdiri dari

a. Berbakti Kepada Allah

b. Memenuhi atau mencukupkan kodrat hidup manusia yang telah menjadi hukum bahwa antara pria dan wanita itu saling membutuhkan.

c. Mempertahankan keturunan umat manusia

d. Melanjutkan perkembangan dan ketentraman hidup rohaniah antara pria dan wanita.

e. Mendekatkan dan saling menimbulkan pengertian antar golongan manusia antar golongan manusia untuk menjaga keselamatan hidup.

\section{Landasan Hukum Perkawinan}

Landasan hukum Perkawinan terdapat dalam Undang - Undang Perkawinan tahun 1974 Pasal 2 ayat (1) dan Pasal 2 ayat (2) yang rumusannya :

Perkawinan adalah sah apabila dilakukan menurut hukum masing-masing agamanya dan kepercayaannya itu. Tiap-tiap perkawinan dicatat menurut peraturan-peraturan, perundang-undangan yang berlaku.

Sedangkan menurut Kompilasi Hukum Islam Dasar perkawinan dalam Kompilasi Hukum Islam Pasal 2 dan 3 disebutkan bahwa :

Perkawinan menurut Hukum Islam adalah pernikahan, yaitu akad yang sangat kuat atau miitsaaqan ghaliizhan untuk mentaati perintah Allah dan melaksanakannya merupakan ibadah.Perkawinan bertujuan untuk mewujudkan kehidupan rumah tangga yang sakinah, mawaddah, dan rahmah.

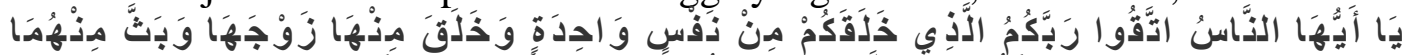

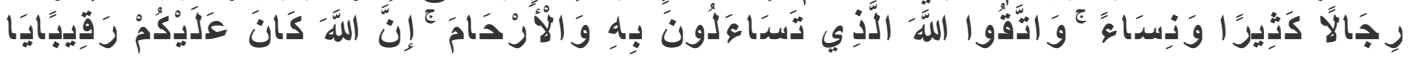
Terjemahnya:

Hai sekalian manusia, bertakwalah kepada Tuhan-mu yang telah menciptakan kamu dari seorang diri, dan dari padanya Allah menciptakan isterinya; dan dari pada keduanya Allah memperkembang biakkan laki-laki dan perempuan yang banyak. dan bertakwalah kepada Allah yang dengan (mempergunakan) nama-Nya kamu saling meminta satu sama lain, dan (peliharalah) hubungan silaturrahim. Sesungguhnya Allah selalu menjaga dan mengawasi kamu. (Q.S. An-nisaa (4):1)

Penjelasan ayat di atas, bahwa:

Maksud dari padanya menurut jumhur mufassirin ialah dari bagian tubuh (tulang rusuk) Adam a.s. berdasarkan hadis riwayat Bukhari dan Muslim. di samping itu ada pula yang menafsirkan dari padanya ialah dari unsur yang serupa Yakni tanah yang dari padanya Adam a.s. diciptakan, dan menurut kebiasaan orang Arab, apabila mereka menanyakan sesuatu atau memintanya kepada orang lain mereka mengucapkan nama Allah seperti : As aluka billah artinya saya bertanya atau meminta kepadamu dengan nama Allah.

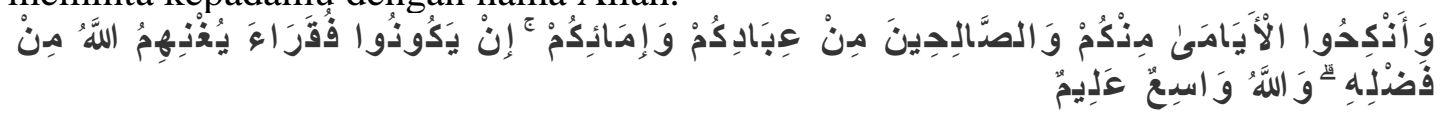


Terjemahnya:

dan kawinkanlah orang-orang yang sedirian diantara kamu, dan orang-orang yang layak (berkawin) dari hamba-hamba sahayamu yang lelaki dan hambahamba sahayamu yang perempuan. jika mereka miskin Allah akan memampukan mereka dengan kurnia-Nya. dan Allah Maha Luas (pemberianNya) lagi Maha mengetahui. (An-Noor (24) :32)

Tambahan penjelasan ayat tersebut, Orang-orang yang sendiria, maksudnya: hendaklah laki-laki yang belum kawin atau wanita- wanita yang tidak bersuami,dibantu agar mereka dapat kawin.

Dari kedua ayat di atas menuntukkan bahwa pengaturan hukum keluarga termasuk hukum perkawinan akan menjamin terpeliharanya sumber daya manusia. Indikasinya adalah bahwa keluarga yang sehat akan melahirkan generasi yang berkualitas tidak hanya segi lahiriah tetapi juga dari segi batiniah. Perkawinan adalah manifestasi dari salah satu unsur fitrah manusia, yaitu adanya hubungan tarikmenarik yang alami antara dua insan yang berbeda, lelaki dan perempuan, Madjid (dalam Andi Syamul Alam, 2010 : 23).

\section{Landasan Usia Perkawinan}

Andi Syamsu Alam (2005 : 47) Landasan hukum tentang ketentuan usia perkawinan akan secara sistematis dapat dipahami dari deskripsi sistematis Undangundang No.1 Tahun 1974 yang secara legimatifnya adalah sebagai berikut:

1. Undang-undang No. 1 Tahun 1974

2. Peraturan Pemerintah Nomor 9 Tahun 1975

3. Intruksi Presiden Nomor 1 Tahun 1991

\section{Implikasi Dispensasi Nikah Dalam Terhadap Kasus Perkawinan}

Dispensasi nikah tidak terlepas pada usia dini perkawinan, seperti yang telah disinggung,usia cukup menjadi peran penting untuk memutuskan menikah, meskpun usia tidak memonopoli alasan dikatannya orang tersebut telah dewasa. Namun, paling tidak dengan usia seseorang dapat dilihat dan dibedakan tentang sejauh mana perjalanan hidupnya dan seberapa besar ia menyikapi apa yang dihadapi. Karena, pengaruh usia perkawinan terhadap kasus-kasus perkawinan di Indonesia secara umum adalah berakhir dengan perceraian. Indikasinya, implikasi usia perkawinan sangat relevan dengan kondisi social-ekonomi masyarakat, yang secara langsung menyangkut aspek antara lain:

1. Keharmonisan Rumah Tangga

Keharmonisan rumah tangga, tidak hanya diukur pada aspek ekonomi semata-mata, akan tetapi sangat begantung pada kesesuaian hasrat dan terpenuhinya hajat hidup batin masing-masing disamping kesesuaian pada aspek social kemasyarakatan;

2. Krisis Akhlak

Dalam konteks akhlak, seorang calon suami atau istri ketika hendak melakukan pernikahan sangat dituntut untuk membangun kepribadian secara utuh. Kepribadian yang dijadikan teladan adalah Rasulullah saw. Dan mengepresikan diri di tengah masyarakat.Akhlak atau tingkah laku manusia relative beragam, sehingga dalam ekspresinya manusia itu selalu diukur tentang perilaku baik atau buruknya.Kecenderungan manusia kepada kebaikan terbukti dari persamaan konsepkonsep pokok moral pada setiap peradaban dan zaman. 
Dalam konteks pembinaan keluarga yang harmonis, maka akhlak yang baik secara kongkrit mempengaruhi perilaku manusia .karena aspek krisis akhlak implikatif dengan soal usia perkawinan. Meamng tidak dapat dinafikkan bahwa aspek ekonomi juga penting akan tetapi dengan kematangan calon suami istri akan lebih kuat mengendalikan rumah tangga dalam menghayati hikmah perkawinan. (Andi Syamsu Alam, 2010: 95)

Abdi Koro (2010 : 41) juga mengatakan, Kenyataan yang tidak dipungkiri pula, bagi pasangan suami istri dibawah umur yakni gejala permasalahan rumah tangga ditimbulkan disebabkan karena kurangnya kematangan jiwa dan pemikiran, rendahnya pendidikan maupun keadaan ekonomi.

\section{Perlindungan Hukum}

Secara umum, perlindungan berarti mengayomi sesuatu dari hal-hal yang berbahaya, sesuatu itu bisa saja berupa kepentingan maupun benda atau barang. Selain itu perlindungan juga mengandung makna pengayoman yang diberikan oleh seseorang terhadap orang yang lebih lemah. Perlindungan hukum bila dijelaskan harafiah dapat menimbulkan banyak persepsi sebelum kita mengurai perlindungan hukum dalam makna yang sebenarnya dalam ilmu hukum, menarik pula untuk mengurai sedikit mengenai pengertian-pengertian yang dapat timbul dari penggunaan istilah perlindungan hukum, yakni Perlindungan hukum bisa berarti perlindungan yang diberikan terhadap hukum agar tidak ditafsirkan berbeda dan tidak cederai oleh aparat penegak hukum dan juga bisa berarti perlindungan yang diberikan oleh hukum terhadap sesuatu. Perlindungan hukum juga dapat menimbulkan pertanyaan yang kemudian meragukan keberadaan hukum.

Oleh karena hukum sejatinya harus memberikan perlindungan terhadap semua pihak sesuai dengan status hukumnya karena setiap orang memiliki kedudukan yang sama dihadapan hukum. Setiap aparat penegak hukum jelas wajib menegakkan hukum dan dengan berfungsinya aturan hukum, maka secara tidak langsung pula hukum akan memberikan perlindungan terhadap setiap hubungan hukum atau segala aspek dalam kehidupan masyarakat yang diatur oleh hukum itu sendiri.

menjalankan dan memberikan perlindungan hukum dibutuhkannya suatu tempat atau wadah dalam pelaksanaannya yang sering disebut dengan sarana perlindungan hukum. Sarana perlindungan hukum dibagi menjadi dua macam yang dapat dipahami, sebagai berikut:

1. Sarana Perlindungan Hukum Preventif

Pada perlindungan hukum preventif ini, subyek hukum diberikan kesempatan untuk mengajukan keberatan atau pendapatnya sebelum suatu keputusan pemerintah mendapat bentuk yang definitif. Tujuannya adalah mencegah terjadinya sengketa. Perlindungan hukum preventif sangat besar artinya bagi tindak pemerintahan yang didasarkan pada kebebasan bertindak karena dengan adanya perlindungan hukum yang preventif pemerintah terdorong untuk bersifat hati-hati dalam mengambil keputusan yang didasarkan pada diskresi. Di indonesia belum ada pengaturan khusus mengenai perlindungan hukum preventif.

2. Sarana Perlindungan Hukum Represif

Perlindungan hukum yang represif bertujuan untuk menyelesaikan sengketa. Penanganan perlindungan hukum oleh Pengadilan Umum dan Peradilan Administrasi 
di Indonesia termasuk kategori perlindungan hukum ini. Prinsip perlindungan hukum terhadap tindakan pemerintah bertumpu dan bersumber dari konsep tentang pengakuan dan perlindungan terhadap hak-hak asasi manusia karena menurut sejarah dari barat, lahirnya konsep-konsep tentang pengakuan dan perlindungan terhadap hak-hak asasi manusia diarahkan kepada pembatasan-pembatasan dan peletakan kewajiban masyarakat dan pemerintah. Prinsip kedua yang mendasari perlindungan hukum terhadap tindak pemerintahan adalah prinsip negara hukum dikaitkan dengan pengakuan dan perlindungan terhadap hak-hak asasi manusia, pengakuan dan perlindungan terhadap hak-hak asasi manusia mendapat tempat utama dan dapat dikaitkan dengan tujuan dari negara hukum.

Perlindungan berarti sebagai cara, proses atau perbuatan melindungi, sedangkan hukum merupakan peraturan-peraturan yang bersifat memaksa yang menentukan tingkah laku manusia dalam lingkungan masyarakat yang dibuat oleh badanbadan resmi yang berwajib. Dalam Deklarasi Hak Anak 1959 yang disahkan oleh PBB pada 20 november 1959, disebutkan bahwa perlindungan anak dibedakan sebagai berikut :

1) Perlindungan yang bersifat yuridis yang meliputi perlindungan dalam :

(1) bidang hukum public

(2) bidang hukum keperdataan

2) Perlindungan non yuridis yang meliputi :

(1) bidang social

(2) bidang kesehatan

(3) bidang kependidikan

\section{Pengertian anak}

Anak adalah karunia Tuhan Yang Maha Esa, yang harus dijaga karena dalam dirinya melekat harkat, martabat, dan hak-hak sebagai manusia yang harus dijunjung tinggi. Anak adalah masa depan bangsa dan generasi penerus cita-cita bangsa, sehingga setiap anak berhak atas kelangsungan hidup, tumbuh, dan berkembang, berpartisipasi serta berhak atas perlindungan dari tindak kekerasan dan diskriminasi serta hak sipil dan kebebasan.

Anak merupakan seseorang yang dilahirkan dari sebuah hubungan antara pria dan wanita. Hubungan antara pria dan wanita ini jika terikat dalam suatu ikatan perkawinan lazimnya disebut sebagai suami istri.

Ditinjau dari aspek yuridis, maka pengertian "anak" dimata hukum positif di Indonesia lazim diartikan sebagai orang yang belum dewasa (minderjaring atau person under age), orang yang dibawah umur atau keadaan dibawah umur (minderjaringheid atau inferionity) atau kerap juga disebut sebagai anak yang dibawah pengawasan wali (minderjarige onvervoodij) Abu hurairah (2006:36).

Kitab Undang-Undang Hukum Perdata memberi batasan mengenai pengertian anak atau orang yang belum dewasa adalah mereka yang belum berumur 21 (dua puluh satu) tahun, seperti yang dinyatakan dalam Pasal 330 yang berbunyi belum dewasa adalah mereka yang belum mencapai umur genap dua puluh satu tahun dan tidak lebih dahulu kawin.

Pengertian anak secara khusus dapat diartikan menurut Undang-Undang Nomor 23 Tahun 2002 tentang Perlindungan Anak Pasal 1 ayat (1), bahwa dimaksud dengan anak adalah seseorang yang belum berusia 18 (delapan belas) tahun, 
termasuk anak yang masih dalam kandungan.Anak sebagai generasi penerus dan pengelola masa depan bangsa perlu dipersiapkan sejak dini melalui pemenuhan hakhaknya yakni hak untuk hidup, tumbuh, berkembang, dan berpartisipasi secara wajar sesuai dengan harkat dan martabat kemanusiaan, serta mendapat perlindungan dari kekerasan dan diskriminasi.

Anak dalam kamus besar bahasa Indonesia diartikan sebagai keturunan,anak juga mengandung pengertian sebagai manusia yang masih kecil. Selain itu,anak pada hakekatnya seorang yang berada pada satu masa perkembangan tertentu dan mempunyai potensi untuk menjadi dewasa.

Berikut ini uraian tentang pengertian anak menurut beberapa peraturan perundang-undangan:

a. Kitab Undang-Undang Hukum Pidana (KUHP)

Pengertian kedudukan anak dalam hukum pidana diletakkan dalam pengertian seorang anak yang belum dewasa, sebagai orang yang mempunyai hakhak khusus dan perlu mendapatkan perlindungan menurut ketentuan hukum yang berlaku. Pengertian anak dalam hukum pidana menimbulkan aspek hukum positif terhadap proses normalisasi anak dari perilaku menyimpang untuk membentuk kepribadian dan tanggung jawab yang pada akhirnya anak tersebut berhak atas kesejahteraan yang layak.

b. Undang-Undang Nomor 23 Tahun 2002 tentang Perlindungan Anak

Pengertian anak menurut Undang-Undang Nomor 23 Tahun 2002 tentang Perlindungan Anak terdapat dalam Bab I Ketentuan Umum. Pasal 1 angka 1 menyebutkan bahwa " Anak adalah seseorang yang belum berusia 18 (delapan belas) tahun, termasuk anak yang masih dalam kandungan".

c. Undang-Undang Nomor 11 Tahun 2012 tentang Sistem Peradilan Pidana Anak

Anak yang menjadi korban tindak pidana yang selanjutnya disebut anak korban adalah anak yang belum berumjur 18 (delapan belas) tahun yang mengalami penderitaan fisik, mental, dan/atau kerugian ekonomi yang disebabkan oleh tindak pidana.

d. Undang-Undang Nomor 39 Tahun 1999 tentang Hak Asasi Manusia

Pengertian anak menurut Undang-Undang Nomor 39 Tahun 1999 tentang Hak Asasi Manusia, terdapat dalam Bab I Ketentuan Umum. Pasal 1 angka 5 menyebutkan " anak adalah setiap manusia yang berusia dibawah 18 (delapan belas) tahun dan belum menikah, termasuk anak yang masih ada dalam kandungan apabila hal tersebut adalah demi kepentingannya".

e. Undang-Undang Nomor 4 Tahun 1979 tentang Kesejahteraan Anak

Pengertian anak menurut Undang-Undang Nomor 4 Tahun 1979 tentang kesejahteraan anak, terdapat dalam Bab I Ketentuan Umum. Pasal 1 angka 2 menyebutkan "anak adalah seseorang yang belum mencapai usia 21 (dua puluh satu) tahun dan belum pernah kawin".

f. Keputusan Presiden RI No. 36 Tahun 1990.

Berdasarkan Keputusan Presiden Republik Indonesia Nomor 36 Tahun 1990 tentang Ratifikasi Konvensi Hak Anak, anak adalah setiap manusia yang berusia dibawah delapan belas tahun kecuali berdasarkan undang-undang lain yang berlaku bagi anak-anak ditentukan bahwa usia dewasa dicapai lebih awal. 
Dengan demikian maka pengertian anak (juvenile) pada umumnya adalah seorang yang masih di bawah umur tertentu, yang belum dewasa dan belum pernah kawin. Pada beberapa peratuaran perundang-undangan di Indonesia mengenai batasan umur berbeda-beda. Perbedaan tersebut bergantung dari sudut manakah pengertian anak dilihat dan ditafsirkan. Hal ini tentu ada pertimbangan aspek psikis yang menyangkut kematangan jiwa seseorang. ( Abintoro Prakoso, 2016:42).

Di sisi lain, beberapa pengertian dan batasan umur anak sebagaimana tersebut di atas, dirasa menjadi perlu untuk menentukan dan menyepakati batasan umur anak secara jelas dan lugas agar nantinya tidak terjadi permasalahan. Dalam batasan ini, batasan umur anak lebih condong mengikuti Undang-Undang tentang Perlindungan Anak.

\section{Perlindungan Anak}

Perlindungan anak adalah segala kegiatan untuk menjamin dan melindungi anak dan hak-haknya agar dapat hidup, tumbuh, berkembang, dan berpatisipasi, secara optimal sesuai dengan harkat dan martabat kemanusiaan, serta mendapat perlindungan dari kekerasan dan diskriminasi (Undang-Undang Nomor 23 Tahun 2002 tentang Perlindungan Anak Pasal 1 Ayat 2). Perlindungan anak di Indonesia berarti melindungi potensi sumber daya insani dan membangun manusia Indonesia seutuhnya, menuju masyarakat yang adil dan makmur, materiil spiritual berdasarkan pancasila dan Undang-Undang 1945.

Upaya-upaya perlindungan anak harus dimulai sedini mungkin, agar kelak dapat berpartisipasi secara optimal bagi pembangunan bangsa dan negara. UndangUndang Nomor 23 Tahun 2002 tentang Perlindungan Anak menegaskan bahwa pertanggungjawaban orang tua, keluarga, masyarakat, pemerintah dan negara merupakan rangkaian kegiatan yang dilaksanakan secara terus-menerus demi terlindunginya hak-hak anak. Upaya perlindungan anak perlu dilaksanakan sedini mungkin, yaitu sejak dari janin dalam kandungan sampai anak berumur 18 (delapan belas) tahun. Undang-Undang Nomor 23 Tahun 2002 tentang Perlindungan Anak meletakkan kewajiban memberikan perlindungan kepada anak berdasarkan asas-asas yaitu:

a. Nondiskriminasi;

b. Kepentingan yang terbaik bagi anak;

c. Hak untuk hidup, kelangsungan hidup, dan perkembangan; dan

d. Penghargaan terhadap pendapat anak.

Upaya perlindungan anak, perlu peran masyarakat, baik melalui lembaga perlindungan anak, lembaga keagamaan, lembaga swadaya masyarakat, organisasi kemasyarakatan, organisasi sosial, media massa, atau lembaga pendidikan. Jadi, demi pengembangan manusia seutuhnya dan peradaban setiap orang wajib mengusahakan perlindungan anak sesuai dengan kemampuan dan kesanggupan dirinya. Setiap anak memiliki hak untuk melaksanakan kewajibannya untuk memperjuangkan kelangsungan hidupnya, tumbuh kemban dirinya, dan perlindungan bagi dirinya.

\section{Tinjauan umum mengenai hak-hak anak}

Hak anak adalah bagian dari hak asasi manusia yang wajib dijamin dilindungi, dan dipenuhi oleh orang tua, keluarga, masyarakat, pemerintah, dan Negara. Setiap anak berhak atas perlindungan dari tindak kekerasan secara fisik 
maupun mental dan diskriminasi serta hak sipil dan kebebasan.Menurut UndangUndang Nomor 23 Tahun 2002 tentang perlindungan anak, hak-hak anak diatur dalam Pasal 4 sampai Pasal 18.

Menurut kodrat alam, manusia selalu hidup bersama (berkelompok). Aristoteles menyatakan dalam ajarannya, bahwa manusia adalah zoon politicon artinya bahwa manusia itu sebagai mahkluk pada dasarnya selalu ingin bergaul dan berkumpul dengan sesama manusia lainnya. Oleh karena sifat yang suka bergaul satu sama lain, maka manusia disebut mahkluk sosial. Sebagai makhluk sosial manusia tidak dapat dipisahkan dari masyarakat. Karena manusia lahi, hidup berkembang dan meninggal dunia di dalam masyarakat.

Adapun yang menyebabkan manusia hidup bermasyarakat ialah adanya dorongan kesatuan biologis yang terdapat dalam naluri manusia misalnya hasrat untuk memenuhi keperluan makan dan minum, hasrat untuk membela diri dan hasrat untuk mempunyai keturunan.

Eksistensi sebagai makhluk sosial menghendaki adanya jalinan atau hubungan antar sesama, hidup berdampingan dan saling membutuhkan satu sama lain (hidup bermasyarakat) yang pada hakikatnya semata-mata untuk kepentingan manusia itu sendiri. Namun manusia diharuskan untuk menunjukan sesuatu yang menjadi jati diri yaitu kemuliaan (self of dignity),kepercayaan diri (self of image), dan harga diri (self esteem) terhadap lingkungan sosial.

Jati diri seseorang lahir sebagai wujud kepemilikan terhadap suatu nilai yang mendasar di dalam dirinya (human rights). Nilai ini kemudian meletakkan dasar kepribadian yang membedakan antara manusia yang satu dengan yang lainnya. Nilai ini selanjutnya dikenal sebagai "hak" dari seorang manusia atau subjek hukum.(Daud A Busroh dan Abu Bakar Busroh,1938:14).

Definisi mengenai hak menurut Bernhard Winscheid, hak adalah suatu kehendak yang dilengkapi dengan ketentuan (macht) dan yang diberikan oleh tertib hukum atau sistem hukum kepada yang bersangkutan. Van Apeldoorn,hak adalah suatu kekuatan (macht) yang diatur oleh hukum. Sedangkan menurut Lamaire, hak adalah sesuatu izin bagi yang bersangkutan untuk berbuat sesuatu. Leon Duguit, mengatakan hak diganti dengan fungsi social yang tidak semua manusia mempunyai hak, sebaliknya tidak semua manusia menjalankan fungsi-fungsi sosial (kewajiban) tertentu (Utrecht,1957:233).

Pengertian-pengertian hak di atas sebagai suatu pengantar untuk memahami atau meletakkan makna dari hak yang sebenarnya. Menurut hukum, pengertian hak adalah izin atau kekuasaan yang diberikan oleh hukum kepada seseorang untuk melakukan sesuatu. Hak dapat dibagi menjadi 2 (dua) bentuk yaitu:

1. Hak mutlak Hak yang diberikan secara langsung kepada seseorang untuk melakukan suatu perbuatan dan yang dapat dipertahankan serta wajib dihormati oleh siapapun. Hak mutlak terbagi menjadi 3 (tiga) golongan yaitu hak asasi manusia, hak publik mutlak, dan hak keperdataan;

2. Hak relatif (hak nisbi) Hak yang diberikan kepada seseorang atau kelompok tertentu untuk menuntut agar supaya seseorang atau kelompok lain memberikan sesuatu, melakukan sesuatu dan/atau tidak melakukan sesuatu.;

Dalam masyarakat setiap orang mempunyai kepentingan sendiri yang berbeda antara manusia satu dengan yang lainnya untuk itu diperlukannya aturan hukum 
untuk menata kepentingan itu. Ketentuan hukum yang menyangkut kepentingan anak disebut hukum perlindungan anak. Hukum perlindungan anak adalah hukum yang menjamin perlindungan hak dan kewajiban anak. Bismar Siregar mengatakan aspek perlindungan anak lebih dipusatkan kepada hak-hak anak yang diatur oleh hukum bukan kewajiban, mengingat secara hukum anak belum dibebani kewajiban. Adapun hak-hak anak diatur dalam Undang-Undang Republik Indonesia Nomor 4 Tahun 1979 tentang Kesejahteraan Anak mengatur hak-hak anak,. Undang-Undang Republik Indonesia Nomor 35 Tahun 2014 tentang Perubahan Atas Undang-Undang Republik Indonesia Nomor 23 Tahun 2002 tentang Perlindungan Anak. Serta dalam Undang-Undang Republik Indonesia Nomor 39 Tahun 1999 tentang Hak Asasi Manusia.

Dari beberapa ketentuan perundang-undangan di atas, maka penulis mengkategorikan hak-hak anak sebagai berikut:

a) Hak untuk hidup, tumbuh, dan berkembang;

b) Hak untuk mendapatkan identitas dan kewarganegaraan;

c) Hak untuk mengetahui orang tua, dibesarkan, dan diasuh orang tuanya;

d) Hak untuk memperoleh pendidikan yang sesuai;

e) Hak untuk memperoleh pelayanan kesehatan dan jaminan sosial;

f) Hak untuk mendapatkan kebebasan beribadah, berekspresi, dan berpikir;

g) Hak untuk memperoleh lingkungan terbaik;

h) Hak untuk mendapatkan perlindungan dari segala hal yang dapat merugikan;

i) Hak untuk mendapatkan Air Susu Ibu (ASI).

Implementasi Dispensasi Nikah Dalam Tinjauan UU No. 23 Tahun 2002 Tentang Perlindungan Anak Di Pengadilan Agama Takalar

Berdasarkan hasil wawancara penulis dengan Hakim di Pengadilan Agama Takalar, serta advokat dan para pihak pemohon 1 dan pemohon II, dijelaskan bahwa dispensasi nikah adalah permohonan hak bagi calon pengantin yang masih berada di bawah umur yaitu usia di bawah 16 tahun bagi wanita dan usia dibawah 19 tahun bagi pria, hal ini telah dijelaskan dalam UU Perkawinan No.1 Pasal 1 ayat (2). Akan tetapi meski telah diatur dalam undang-undang, polemik mengenai dispensasi nikah pun, tidak serta merta terlepas dari berbagai kendala ataupun persoalan yang dihadapi oleh hakim pengadilan agama Takalar.

Sebagai warga Makassar, tentu sangat menjunjung tinggi dan memelihara adat kesopanan yang dikenal dengan istilah siri' yang merpakan harga diri yang harus dijaga oleh setiap individunya, hal ini biasa dikaitkan pada keadaan untuk menutupi kekurangan terhadap sesuatu yang dianggap akan mengundang atau membuka aib yang telah atau bahkan sebelum terjadi.

Terlepas dari upaya penjagaan, kondisi zaman yang semakin berkembang dan nyaris sulit terkendali, sangat berpotensi membawa dampak negative bagi remaja yang seharusnya masih membutuhkan pengawasan dan bimbingan dengan tepat dan tegas oleh orang tua dan orang terdekatnya.Longgarnya kendali dan peraturan nyaris membawa anak-anak tersebut pada perjalanan yang mengancam masa depannya. Tidak sedikit gaya pacaran atau pergaulan yang dilihat hari ini sudah melampaui batas hingga di usia mereka yang masih muda telah terjebak pada pergaulan bebas. 
Gejolak perasaan.rasa ingin tahu yang tidak tersalurkan dengan baik menjadi salah satu alasan membuat masa muda mereka tergadaikan.

Ada sekitar $40 \%$ karena si wanita hamil di usia muda namun tidak sedikit pula yang tidak hamil hingga akhirnya membawa mereka ke pengadilan agama untuk melakukan permohonan dispensasi nikah (Ibu Musafirah,S.Ag.,M.H) hakim Pengadilan Agama Takalar. Wawancara 08 Oktober 2018).

Hal senada pun disampaikan oleh Ibu Nurakhriyani zainal,S.H,M.H selaku hakim di Pengadilan Agama Takalar (Wawancara 08 Oktober 2018). Bahwa ada beberapa yang mengajukan permohonan dispensasi nikah adalah mereka yang telah hamil di luar nikah.Namun, tidak hanya itu, meskipun belum hamil, kedekatan anak perempuan dan anak laki-laki yang dianggap sulit untuk dipisahkan, juga menjadi alasan bagi orangtua mereka untuk segera menikahkan anaknya.

Selanjutnya, ditambahkan oleh bapak. Muh. Hasyim,Lc (Wawancara 09 Oktober 2018), adanya faktor ekonomi yang terkadang menjadi alasan untuk segera menikahkan anaknya hingga dalam hal ini terkesan memaksakan anak untuk dewasa sebelum waktunya, akhirnya tidak sedikit dari mereka yang pernah pengajukan permohonan dispensasi nikah dan dikabulkan oleh hakim namun berakhir pada perceraian karena belum adanya kesiapan anak untuk berumah tangga dalam mengemban tanggung jawab dan terbilang belum matang dalam membina rumah tangga.

Meski dalam rentang waktu tahun 2015-2017 permohonan dispensasi nikah di Pengadilan Agama mengalami kenaikan setiap tahunnya, akan tetapi majelis hakim tidak serta merta mengabulkan permohonan yang masuk. Diketahui bahwa setiap perkara yang masuk ke dalam pengadilan agama, itu berarti hakim tidak boleh menolak ataupun memilah perkara yang akan ditanganinya karena hal demikian menjadi hak bagi para pencari keadilan dan tentu hal itu sudah kewajiban hakim untu menerima, menimbang, mengadili dan menetapkan/memutuskan perkara yang masuk. Dalam proses persidanganlah kemudian hakim berupaya memberikan jalan keluar untuk meyelesaikan masalah yang dihadapi oleh para pemohon, kalaupun masih bisa ditangani dengan baik dan diselesaikan tanpa harus melewati penyelesaian melalui dikabulkannya permohonan dispensasi nikah pemohon, maka hakim berupaya untuk menggali lebih dalam demi kemaslahatan sang anak untuk kedepannya.

Meskipun perkara dispensasi nikah di pengadilan agama semakin bertambah setiap tahunnya akan tetapi jika dilihat dari data di atas menunjukkan bahwa, tidak semua permohonan dispensasi nikah dikabulkan. Karenanya hakim selalu berupaya untuk menggali dan lebih berhati-hati dalam menetapkan permohonan dispensasi nikah, sekalipun jika harus mengesampingkan undang-undang tanpa mengabaikannya. Melihat kemaslahatan keluarga dan rumah tangga, perkawinan hanya boleh dilakukan calon mempelai yang telah mencapai umur yang ditetapkan dalam pasal 7 Undang-undang No. 1 tahun 1974 disyaratkan adanya batas kedewasaan sebagaimana disebutkan bahwa "Perkawinan hanya diizinkan jika pihak pria sudah mencapai umur 19 (sembilan belas) tahun dan pihak wanita sudah mencapai umur 16 (enam belas) tahun. Bagi calon mempelai yang belum mencapai umur 21 tahun harus mendapat izin sebagaimana yang diatur dalam pasal 6 ayat (2), (3), (4) dan (5) UU No. 1 Tahun 1974. 
Bapak Muh. Hasyim, Lc, selaku Hakim Pengadilan Agama Takalar juga mengatakan bahwa undang-undang perkawinan ini tidak perlu direvisi karena pada dasarnya kekuasaan kehakiman merupakan salah satu bentuk kekuasaan yang bersifat merdeka. Hal ini dimaksudkan untuk menjaga legitimasi dan wibawa dari badan Peradilan itu sendiri yang dapat dijadikan dasar pertimbangan hakim dalam mengabulkan dispensasi perkawinan di bawah umur di Pengadilan Agama Takalar.

Jika dinilai bahwa Undang-Undang Perkawinan sudah tidak representatif lagi dengan kondisi saat ini, maka perlu diketahui bahwa tidak ada satupun norma/hukum yang sempurna, dan tidak ada satu kaedah hukum pun yang telah dipositifkan namun tidak memiliki celah. Bahwa ketika hukum telah dikodifikasi, maka pada saat itu juga hukum sudah tertinggal oleh pergeseran sosial yang terjadi. Sebagaimana diketahui bahwa pengadilan tidak memiliki kewenangan membuat undang-undang, akan tetapi yang menjalankan dan berupaya menggali dan menemukan hukum. Bapak. Muh. Hasyim,Lc. Hakim pengadilan Agama Takalar, berpendapat bahwa Undang-undang ini tidak perlu di revisi.(Wawancara 09 oktober 2018).

Implementasi dispensasi nikah dalam tinjauan undang-undang perlindungan anak di pengadilan agama takalar kurang efektif karena masih adanya permohonan dispensasi nikah yang kabulkan tanpa menjadikan undang-undang perlindungan anak sebagai salah satu bahan pertimbangan.

\section{PENUTUP}

\section{Kesimpulan}

Berdasarkan pembahasan dari hasil penelitian yang telah diuraikan, maka dapat disimpulkan sebagai berikut:

1. Pelaksanaan Undang-undang Nomor 23 Tahun 2002 tentang Perlindungan Anak di Pengadilan Agama Takalar kurang efektif, karena majelis hakim tidak mempertimbangkan usia anak yang masih dibawah umur serta hak-hak anak yang telah diatur dalam undang-undang perlindungan anak.

2. Faktor-faktor yang mempengaruhi dispensasi nikah dalam tinjauan Undangundang Nomor 23 Tahun 2002 Tentang Perlindungan Anak di Pengadilan Agama Takalar hanya 2 (dua) yaitu struktur hukum dan budaya hukum.

\section{Implikasi}

1. Hendaknya Majelis Hakim menjadikan Undang-undang perlindungan anak sebagai bahan pertimbangan dalam memutus perkara permohonan dispensasi nikah. Hal ini dilakukan demi terciptanya putusan yang benar dan seadiladilnya.

2. Diperlukan adanya penyuluhan hukum kepada masyarakat untuk dapat menciptakan kesadaran hukum agar masyarakat taat dan patuh pada aturanaturan khususnya mengenai Dispensasi Nikah dalam kaitannya dengan Undang-undang Perlindungan Anak. 


\section{DAFTAR PUSTAKA}

Ahmad Rofiq. Hukum Islam Di Indonesia. Jakarta: PT. Raja Grafindo Persada, 1995. Alam, Andi Syamsu. Usia Ideal Memasuki Perkawinan. Jakarta: Kencana Mas. 2005.

, Reformasi Peradilan Agama di Indonesia. Jakarta: Yapensi. 2004.

Ali, Achmad. Menguak Teori Hukum (Legal Theory) dan Teori Peradilan (Judicial Prudence) Termasuk Interprestasi Undang-Undang (Legis Prudence). Jakarta: Kencana. 2009.

Arif Gosita. Masalah Perlindungan Anak. Jakarta: CV. Akademika Pressindo. 1987.

Arief, Barda Nawawi. Kapita Selekta Hukum Pidana. Cet. III; Bandung: Citra Aditya 2013.

As'sad, Abdul Muhaimin. Risalah Nikah. Surabaya: Bintang Terang. 1986

Athar, Radhawi Said. Keluarga Islam. Bandung: Risalah. 1985.

Badan Pembinaan Hukum Nasional. Kementrian Hukum dan HAM RI, Jakarta.

Bahry, Zainal. Kamus Umum. Angkasa. Bandung. 1996.

Basyir, Ahmad Azhar. Hukum Perkawinan Islam. Yogyakarta: Universitas Islam Indonesia. 1980.

Bayyinatul Muchtaromah. Pendidikan Reproduksi Bagi Anak Menuju Aqil Balik. Malang: UIN Malang Press. 2008.

Departemen Agama RI. Kompilasi Hukum Islam di Indonesia. Jakarta: Direktorat Jenderal Pembinaan Kelembagaan Agama Islam. 2000.

Departemen Agama RI. Al-Qur'an dan Terjemahnya. Surabaya: Mekar. 2004.

Djil, Basiq Pengadilan Agama Di Indonesia : Gemuruhnya Politik Hukum (Hukum Islam, Hukum Barat, Hukum Adat) Dalam Rentan Sejarah Bersama Pasang Surut Lembaga Peradilan Syariat Islam Aceh.

Doyle, Paul Johnson. Teori Sosiologi Klasik dan Modern. Jakarta: Gramedia. 1986.

Gultom,Maidin. Perlindungan Terhadap Anak. Bandung: PT. Refika Aditama. 2008.

Hadikusuma, Hilman. Hukum Perkawinan Indonesia Menurut Perundangan,Hukum Adat Dan Hukum Agama. Bandung: Mandar Maju. 1990.

Hakim, Rahmat. Hukum Perkawinan Islam. Bandung: Pustaka Setia. 2000.

Harahap, Yahya. Hukum Perkawinan Nasional. Medan: Zahir Trading. 1975.

Harahap, Yahya. Hukum Perkawinan Nasional. Medan: Cv Zahir. 1979.

Harahap, Yahya. Hukum Acara Perdata. Jakarta: Sinar Grafika. 2005.

Harjono, Anwar. Hukum Islam: Kekuasaan dan Keadilannya. Jakarta: Bulan Bintang. 1989.

Husein, Muhammad. Fiqh Perempuan (Refleksi Kiai atas Wacana Agama dan Gender). Yogyakarta: LKIS. 2001.

Kamil, Ahmad dan M. Fauzan. Kaidah-Kaidah Hukum Yurispurdensi. Jakarta: Chandra Pratama, 2004. 
Kelsen, Tentang Hukum, ctk. Kedua, Jakarta: Konstitusi Press. 2012

Kelsen, Hans. General Teory of Law and State, Translete by Anders Wedberg, New York: Russel and Russel, dikuitip dari Jimly Ashidiqqie dan M ali Safa'at, Teori Hans. 19991

Kuzari, Ahmad. Nikah Sebagai Perikatan. Badan Penelitian IAIN Walisongo. Bandung.1995.

Manan, Abdul. Penerapan Hukum Acara Perdata di Lingkungan Peradilan Agama. Jakarta: Kencana. 2005.

Mappiare, Andi. Psikologi Remaja. Surabaya: Usaha Nasional. 1982.

Mariyadi, , Afandi,. Hukum Acara Perdata II (Panduan Pengembangan Profesi Hukum). VISIPRESS MEDIA. 2008

Mertokusumo, Sudikno. Hukum Acara Perdata Indonesia. Edisi Ketiga. CetI; Yogyakarta: Libery,1988.

Mertokusumo, Sudikno. Hukum Acara Perdata Indonesia. Yogjakarta: Libery. 1995.

Moleong, J.L. Metodologi Penelitian Kualitatif. Bandung: Rosdakarya, 2003.

Muchtar, Kamal. Asas-asas Hukum Islam Tentang Perkawinan. Jarkarta: Bulan Bintang. 2004.

Muhammad, Abdul Kadir. Hukum Acara Perdata Indonesia. Bandung: PT. Citra Aditya Bakti. 2000.

Nur, Taufik. Fikih Rumah Tangga. Jakarta: eLSAs. 2010.

Nur, Dwi Utami Hudaya. Efektifitas Pelaksanaan saksi Keluarga Dalam Perkara Perceraian Menurut Pasal 172 Ayat (1) Di Pengadilan Agama Makassar. Makassar: Ilmu Hukum, Universitas Muslim Indonesia. 2017.

Paton, G.W.A. Texbook of Jurisprudence. Terjemahan J. Satrio, edisi kedua, At the Clarendon. Press. Ocford. 1951.

Rahardjo, Satjipto. Masalah Penegakan Hukum. Bandung: Sinar Baru. 1983.

Rahardjo, Satjipto. Sisi-sisi Lain dari hukum di Indonesia. Jakarta: Kompas. 2009.

Rasyid, Roihan A. Hukum Acara Peradilan Agama. Jakarta: RajaGrafindo Persada, 1998.

Rasyid. Raihan A. Hukum Acara Peradilan Agama. Jakarta: Rajawali Press. 1995.

Robert B seidma. Law order and Power.Adition Publishing Company Wesley Reading massachusett. 1972.

Sampara, Said dan La Ode Husen. Metode Penelitian Hukum. Makassar: Kretakupa. 2016.

Sastroatmodjo, Arso dan Wasit Aulawi.. Hukum Pernikahan di Indonesia. Cet.I; Jakarta: Bulan Bintang. 1975.

Soekanto, Soerjono. Faktor-Faktor yang Mempengaruhi Penegakan Hukum. Jakarta: PT. Raja Grafindo Persada. 2008.

Sudarsono. Hukum Perkawinan Nasional. Cet. III; Jakarta: Rineka Cipta, 2005.

Sudirman, Antonius. Hati Nurani Hakim dan Putusannya. Bandung: PT. Citra Aditya Bhakti. 2007. 
Supramono, Gatot. Segi-Segi Hukum Hubungan Luar Nikah. Jakarta: Djambatan. 1998.

Taneko,Soleman B. Pokok-Pokok Studi Hukum dalam Masyarakat. Jakarta: Rajawali Press , 1993.

Thayib. Anshari Struktur Rumah Tangga Muslim. Cet. III; Surabaya: PT. Risalah Gusti. 1994.

Tobing, Raida L,dkk, (Hasil Penelitian). Efektivitas Undang-Undang Monrey Loundering. 2011.

Utrecht. Pengantar Dalam Hukum Indonesia.

Ichtiar. Wantjik, Saleh. Hukum Perkawinan Indonesia. Ghalia Indonesia. 1983

Wibowo, Basuki Rekso. Peran Hakim dalam Perkembangan Hukum dalam Projustitia. Bandung: Tahun XV No. 4, Andira. 1997.

Wulansari, Dewi. Sosiologi Konsep dan Teori. Bandung. 2009.

Hanafi, Yusuf. Kontroversi Perkawinan Anak Di Bawah Umur (Child Marriage). Bandung: Cv. Mandar Maju. 2011.

Yusuf, Kadar M. Tafsir Ayat Ahkam (Tafsir Tematik Ayat-ayat Hukum). Jakarta: Amza. 2013.

Zubaedah, St. Dispensasi Kawin Dalam Tinjauan Undang-Undang Nomor 23 Tahun 2002 Tentang

Perlindungan Anak,(Online).https://drive.google.com/file/d/0B3WN1LmqvT7IeFNJT1VhS Td0SnM/viewdiakses 23 Oktober 2017). 